\title{
Analysis on the Contribution of Agricultural Sector on the Economic Development of Ghana
}

\author{
Abban Priscilla Nyamekye ${ }^{1}$, Ze Tian $^{1 *}$, Fangfang Cheng ${ }^{2}$ \\ ${ }^{1}$ Business School, Hohai University, Nanjing, China \\ ${ }^{2}$ School of Economics and Management, Zhejiang University of Science and Technology, Hangzhou, China \\ Email: `200316655@hhu.edu.cn
}

How to cite this paper: Nyamekye, A. P. Tian, Z., \& Cheng, F. F. (2021). Analysis on the Contribution of Agricultural Sector on the Economic Development of Ghana. Open Journal of Business and Management, 9, 1297-1311.

https://doi.org/10.4236/ojbm.2021.93070

Received: April 19, 2021

Accepted: May 25, 2021

Published: May 28, 2021

Copyright (c) 2021 by author(s) and Scientific Research Publishing Inc. This work is licensed under the Creative Commons Attribution International License (CC BY 4.0).

http://creativecommons.org/licenses/by/4.0/

\begin{abstract}
The study empirically examines the impact of agricultural sector on the economic GDP growth of Ghana, using time series data from 1984 to 2018. The cointegration test results showed the non-existence of long-run relationships existing between the overall GDP and agricultural output. In its set-up, the error correction method estimates the long-run relationship between economic growth and agricultural output as well as fluctuation in the short-run. Based on the basic regression model, agricultural output exhibits a significantly positive impact on the overall GDP growth of the country. Similarly, the industrial and service sector also contributed positively to overall GDP growth. The results indicate the need to promote value added agricultural export expansion policies to achieve high economic GDP growth.
\end{abstract}

\section{Keywords}

Agricultural Output, Economic GDP Growth, Industrial Sector, Service Sector

\section{Introduction}

Agriculture plays a crucial role in contributing to socio-economic development in many countries. It is the primary source of employment, livelihood, and food security for the majority of rural people. In the year 2019, the agricultural sector contributed about $20 \%$ to Ghana's gross domestic product (GDP). This sector does not only contribute to Ghana's GDP but also absorbs a lot of labor forces and then provides raw materials for industrial growth and development. In Ghana, the GDP growth rate was $8.4 \%$, while that of the agricultural growth rate was $6.3 \%$ in the year 2018. The overall economic growth and development of a country depend upon the health of the agricultural sector. The reasons are that it provides food, raw materials, and foreign exchange, which further pushed indu- 
strialization in Ghana (Johnston, 1970).

Many researchers have found evidence that either agriculture affects economic growth positively, negatively, or no evidence at all (Enu, 2014; Sertoğlu, Ugural, \& Bekun, 2017; Subramaniam, 2010). For instance, Tiffin and Irz (2006) found that there is enough evidence that supports the conclusion that agricultural is the leading cause of the overall growth rate. Timmer (2005) also correlated poverty with growth in agricultural output and found out that at the provincial level, about two-thirds of the reduction in poverty was due to the growth of agricultural production.

In Ghana, the agricultural sector has been identified as a significant contributor to economic GDP growth. Unfortunately, studies on the impact of agriculture and sub-sectors of economic growth in Ghana are limited. As a result, this study seeks to investigate the effect of the agricultural sector on Ghana's economic growth and determine which sub-sectors of the economy contribute significantly to GDP growth.

The rest of the paper is structured as follows: the second section presents the literature review and the third section describes the methodology and the data used in this study. In the fourth section, we discuss the results of the analysis. Section five concludes the study and gives recommendations.

\section{Related Literatures}

\subsection{Agricultural Sector of Ghana}

The agricultural sector is vital to economic growth and development of Ghana. In the national development agenda, agriculture is identified as a sector that can lead the growth and structural transformation of the economy to maximize the benefits of accelerated growth (MoFA, 2016). The agriculture is the largest employer, accounting for over 45.38 per cent of the total workforce, according to the Ghana Statistical Service (GSS), 2019 report. Figure 1 shows the national distributional share of employment by agricultural sector from 2009 to 2019 .

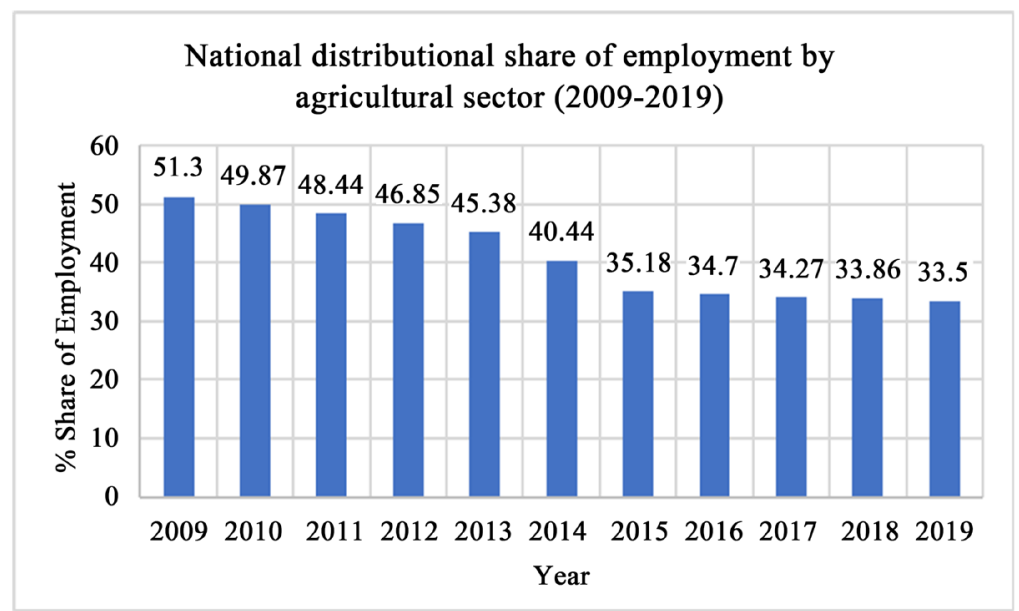

Figure 1. National distributional share of employment by agricultural sector (2009-2019). 
According to Figure 1, 51.3\% of the national distributional share of employment came from the agricultural sector in the year 2009. Since 2009, the percentage share reduced each year by approximately 1\% until 2014 which accounted for $40.44 \%$ after its share of $45.38 \%$ in 2013 . From 2015, the national distributional share of employment by agricultural sector continued to decrease as the position of the agricultural sector was dislodged by the service sector which has the fastest growing sector until it was taken by the industrial sector. Agricultural crops, including yams, grains (cowpea, groundnut, maize, rice, soybean and millet), cocoa, oil palms, kola nuts, and timber form the basis of Ghana's agricultural production.

\subsection{Theories about the Contribution of Agricultural Development to Economic Output}

The following are theories about the contribution of agricultural development to economic output; Structuration theory explains how farmers make use of both authoritative and allocative resources in their areas for agricultural activities. In this theory, allocative resources are those that the farmers have little or no control over, but it still a determinant for their success and examples are rain and roads. To facilitate the agricultural activities of subsistence farmers, roads serve as a bridge in facilitating easy access to agricultural inputs. Giddens was the one who identified these two types of resources, and they are authoritative and allocative resources (Zamora \& Giddens, 1985). Peet (1998) explained authoritatively as capabilities that generate command over the human agent. Authoritative resources come in when you make use of status, power, rules, and norms. Bonsu (2014) used this theory to elaborate on why farmers produced staple crops despite roads giving access to market and farm inputs. In his analysis, he mentioned that structuration theory shows how farmers who stand for agent and resources which correspond to structures come together to explain human action.

Frontier Model is all about the opening up of forests and jungles, which have favorable soil conditions and closer to river basins and using these new places for cultivations. This can be seen in the village economies of Europe, Asia, and Africa, where there was the establishment of new villages in a series from the system of shifting cultivating to short fallow systems and then annual cropping (Udemezue \& Osegbue, 2018). In the history of Western countries, one way of increasing agricultural production was the expansion of areas they cultivated, and this is witnessed in the opening up of new continents during the $18^{\text {th }}$ and $19^{\text {th }}$ centuries (Hayami \& Ruttan, 1971).

Conservation Model is whereby there is a sequential use of labor-intensive cropping systems and the use of organic manures and other physical facilities to use land and water resources available for production effectively. The use of these organic manures and cropping systems will help preserve the land and always be able to produce a healthy and more abundant harvest. Researches show that agricultural development that happened with the conservation model was 
successful as there was a sustaining rate of growth around $1 \%$ per year in agricultural production (Udemezue \& Osegbue, 2018).

\subsection{Empirical Literatures}

In the article by Bonsu (2014), he analyzed the influence of road access on agricultural production as well as its impact on the marketing of agricultural produce. In his study, he mentioned that getting access to roads enables easy and faster access to agricultural inputs and machines, which will allow farmers to produce at a convenient yet still a higher rate. He mentioned that inputs like agrochemicals are not only dependent on the access to roads but also on their effectiveness and adequacy. In this article, he made use of the structuration theory in explaining how farmers make use of both authoritative and allocative resources in their areas for agricultural activities. The results of his findings show that with both allocative and authoritative resources, farmers can promote agricultural production, which will then contribute to the growth of the country.

An analysis was made on the relationship between agricultural resources and economy in Nigeria by Olajide, Akinlabi, and Tijani (2010) using the least square regression method in analyzing the data. The results of his findings show that there is a positive relationship between the Gross Domestic Product and agricultural output in Nigeria. Multiple regression analysis was used by Oji-Okoro (2011) in examining the role that the agricultural sector has played in Nigeria's economic development. In his study, there was a positive relationship between GDP, agriculture, and Foreign Direct Investment. Sertoğlu et al. (2017) also concluded in his paper that agriculture plays an essential role in developing countries. In his research, he used the Johansen multivariate cointegration test and also employed annual time series data in analyzing the long-run impact of the agricultural sector on the economic growth of Nigeria. The agricultural sector of Ghana and its economic impact on economic growth was analyzed by Enu (2014). He employed time series data on the three sectors in Ghana, which are service, industrial, and agriculture, as well as various sub-sectors of agriculture. He also used a regression model and OLS in estimating the respective impact of agriculture, service, and industry on GDP growth. The results of his findings showed that agricultural output has a positive impact on Ghana's growth compared with the other sectors.

Self and Grabowski (2007) confirmed that agricultural technology and its modernization have a positive effect on economic growth and human development by the use of cross-country analysis on the role agricultural technology plays in economic development.

\section{Methodology}

\subsection{Data Sources}

Annual time-series data from 1984 to 2018 were collected from the World Bank. 
These data are used to identify the agricultural sector among different sectors (service, industrial) of Ghana on its economic growth. Subsequently, the various sub-sectors of the economy are also explored to identify their contributions to the overall sector of economic growth.

\subsection{Analytical Framework}

\section{Unit root test}

Empirical research based on time series presumes that observed data are stationary. That is, such a series has a mean; variance and autocovariance at several lags are time-invariant. However, most macroeconomic variables exhibit trends. That is, they grow over time. Thus, the implication of working with non-stationary series results in spurious regression, Granger and Newbold (1974), and Nelson and Plosser (1982). Therefore, forecasting and policy implications drawn from such spurious regression analysis would be misleading. A possible way out is to employ the use of unit root testing procedures to ascertain the stationarity of the series and order of integration of the series. This study employs the well-known tests, namely augmented Dickey-Fuller (ADF) propounded by Dickey and Fuller (1981) test, Phillip-Perron test by Phillip and Perron (1990). The general form of the unit root test is given below:

$A D F$ equation:

$$
\Delta Y_{t}=\beta_{1}+\beta_{2} t+\delta Y_{t-1}+\sum_{i=1}^{m} \Delta Y_{t-i}+\epsilon_{t}
$$

where $\epsilon_{t}$ denotes Gaussians white noise that is assumed to have a mean value of zero, and possible autocorrelation represents series to be regressed on time $t$. The ADF has two hypotheses. Where the null state's series has the unit root and the alternative states stationary. The study also engages an alternative test for unit root propounded by PP in 1988. The PP test is semi-parametric and has similar hypotheses to the ADF. This study for the validity of the stationarity properties of the series uses the Kwiatkowski-Phillips-Schmidt-Shin (KPSS) test to confirm the outcome of the ADF and PP test.

\section{Cointegration test}

Most macroeconomic variables like economic growth in terms of GDP, agricultural output, service output, and industrial output are not stationary at their levels form since they exhibit trend or/and seasonality. To analyze the long-run relationship between the variables in the model, a cointegration test is employed. Granger (1981) and Engle and Granger (1987) recommended a cointegration test to determine the long-run relationship among the series. The Johansen (1988) cointegration test with lags is defined below;

$$
\Delta Y_{t}=\Gamma_{1} \Delta X_{t-1}+\cdots+\Gamma_{k-1} \Delta X_{t-k+1}+\Pi X_{t-k}+\mu+e_{t}
$$

\section{Error correction model}

For a long-run association, variables have to be integrated at the same order. Cointegration depicts that there exists a possible convergence in the long-run among series. Series reach their equilibrium level in the long-run by adjustment 
with time. The vector error correction term procedure is employed with the error correction term. The error correction term coefficient is required to be negative and statistically different from zero, indicating the functionality of the error correction mechanism. It shows the speed of adjustment of the variable toward their long-run values.

\section{Empirical model}

The following endogenous growth model is specified to achieve the objectives of the study.

$$
\text { NGrowth }=f(\text { Agric, Serv, Indust })
$$

where NGrowth is the national economic growth of Ghana, Agric is the log of agricultural sector output, Serv is the log of the service output, and Indust is the $\log$ of industrial output. All these are expressed as a percentage of GDP growth.

\section{Data analysis}

The study will employ both descriptive and inferential analysis in achieving the objectives of the study. The descriptive statistics will include mean and standard deviation and correlational analysis. The inferential analysis will entail the analytical methods described. The econometric software Stata 15 was used for the analysis.

\section{Results and Discussions}

The results of the trends and impact of the agricultural sector on economic growth in Ghana from the period 1984 to 2018 are discussed here. It encompasses the descriptive statistics of the variables employed and their trends over the years. The subsequent sections present the results of the econometric analysis for the main objective to test the causal linkage between the overall GDP growth and agricultural GDP of Ghana.

\subsection{Data Presentation}

This study made use of annual time series data which were collected for a period of 34 years from 1984 to 2018 . The data is presented in Table 1 .

\subsection{Descriptive Statistics}

From Table 2, it is observed that overall GDP has a positive relationship with the agricultural sector GDP $(\mathrm{r}=0.2921, P<0.10)$, industrial sector $(\mathrm{r}=0.8142, P$ $<0.001)$ and service sector GDP $(\mathrm{r}=0.5030, P<0.05)$. The summary statistics of the variables indicate that the industrial sector had the highest mean GDP growth followed by the service and the agricultural sector between the period 1984 and 2018. However, notwithstanding their magnitude all the sectors contributed positively to the overall GDP growth of the country. The agricultural sector has been major contributor to overall GDP and is the backbone of the country, its impact on the economic growth is the least. This is because the GDP 
A. P. Nyamekye et al.

Table 1. GDP growth figures by sectors (\%) (1984-2018).

\begin{tabular}{|c|c|c|c|c|}
\hline Year & Overall GDP & Agriculture & Industry & Service \\
\hline 1984 & 8.6 & 9.7 & 9.0 & 6.9 \\
\hline 1985 & 5.1 & 0.6 & 17.6 & 7.8 \\
\hline 1986 & 5.2 & 3.3 & 7.6 & 7.1 \\
\hline 1987 & 4.8 & 0.0 & 11.5 & 9.0 \\
\hline 1988 & 5.6 & 3.6 & 7.3 & 7.8 \\
\hline 1989 & 5.1 & 4.2 & 2.6 & 6.7 \\
\hline 1990 & 3.3 & -2.0 & 6.9 & 7.9 \\
\hline 1991 & 5.3 & 4.7 & 3.7 & 6.3 \\
\hline 1992 & 3.9 & -0.6 & 5.8 & 7.7 \\
\hline 1993 & 4.9 & 2.5 & 4.3 & 7.2 \\
\hline 1994 & 3.3 & 1.9 & 3.5 & 5.0 \\
\hline 1995 & 4.1 & 3.7 & 4.1 & 4.7 \\
\hline 1996 & 4.6 & 5.2 & 4.7 & 4.2 \\
\hline 1997 & 4.2 & 4.3 & 6.4 & 6.5 \\
\hline 1998 & 4.7 & 5.1 & 3.2 & 6.0 \\
\hline 1999 & 4.4 & 3.9 & 5.0 & 5.0 \\
\hline 2000 & 3.7 & 3.1 & 3.8 & 5.4 \\
\hline 2001 & 4.0 & 4.0 & 2.9 & 5.1 \\
\hline 2002 & 4.5 & 4.4 & 4.7 & 4.7 \\
\hline 2003 & 5.2 & 6.1 & 5.1 & 4.7 \\
\hline 2004 & 5.6 & 7.5 & 5.1 & 4.7 \\
\hline 2005 & 5.9 & 4.1 & 7.7 & 6.9 \\
\hline 2006 & 6.4 & 4.5 & 7.2 & 6.1 \\
\hline 2007 & 4.3 & -1.7 & 6.1 & 7.7 \\
\hline 2008 & 9.1 & 7.4 & 15.1 & 8.0 \\
\hline 2009 & 4.8 & 7.2 & 4.5 & 5.6 \\
\hline 2010 & 7.9 & 5.3 & 6.9 & 9.8 \\
\hline 2011 & 14.0 & 0.8 & 41.6 & 9.4 \\
\hline 2012 & 9.3 & 2.3 & 11.0 & 12.1 \\
\hline 2013 & 7.3 & 5.7 & 6.6 & 10.0 \\
\hline 2014 & 2.9 & 0.9 & 1.1 & 5.4 \\
\hline 2015 & 2.2 & 2.3 & 1.1 & 3.0 \\
\hline 2016 & 3.4 & 2.9 & 4.3 & 2.8 \\
\hline 2017 & 8.1 & 6.1 & 15.7 & 3.3 \\
\hline 2018 & 6.3 & 4.8 & 10.6 & 2.7 \\
\hline
\end{tabular}

Source: World Bank Sub-Sahara Africa data \& Ghana Statistical Service, 2020. 
growth is based on the differences in yearly values expressed as percentage and if the change or the difference is insignificant the growth will be low and vice versa.

\subsection{Sectoral and Overall GDP Trend of Ghana (1984-2018)}

Figure 2 shows the pattern of the variables studied in terms of GDP growth over the years. From panel A, the overall GDP growth saw a drop from 1984 going and an oscillating movement till is saw a rise in 2008. It subsequently declined and saw a big jump and a fall thereafter. The agricultural GDP growth (Panel B) also saw a sharp decline from 1984 and witness and oscillating movement with a sharp drop in 2011 and 2014. The poor performance of the agricultural sector could be explained by the decline in government allocation of resources to the sector over the years that is mostly dominated by smallholder

Table 2. Correlation matrix and descriptive statistics.

\begin{tabular}{ccccc}
\hline & Overall GDP & Agricultural GDP & Industrial GDP & Service GDP \\
\hline Overall GDP & 1 & & & \\
Agricultural GDP & $0.2921^{*}$ & 1 & & \\
Industrial GDP & $0.8142^{* *}$ & -0.1218 & 1 & \\
Service GDP & $0.5030^{* *}$ & -0.2531 & $0.3763^{* *}$ & 1 \\
Mean & 5.4921 & 3.6528 & 7.5548 & 6.3736 \\
SD & 2.2912 & 2.6135 & 7.0765 & 2.1647 \\
Variance & 5.2497 & 6.8303 & 50.0762 & 4.6860 \\
Skewness & 1.7220 & -0.1919 & 3.4062 & 0.4049 \\
Kurtosis & 6.8125 & 2.9900 & 16.5915 & 2.9846 \\
\hline
\end{tabular}

Percentage sectoral and overall GDP growth of Ghana (1984-2018)
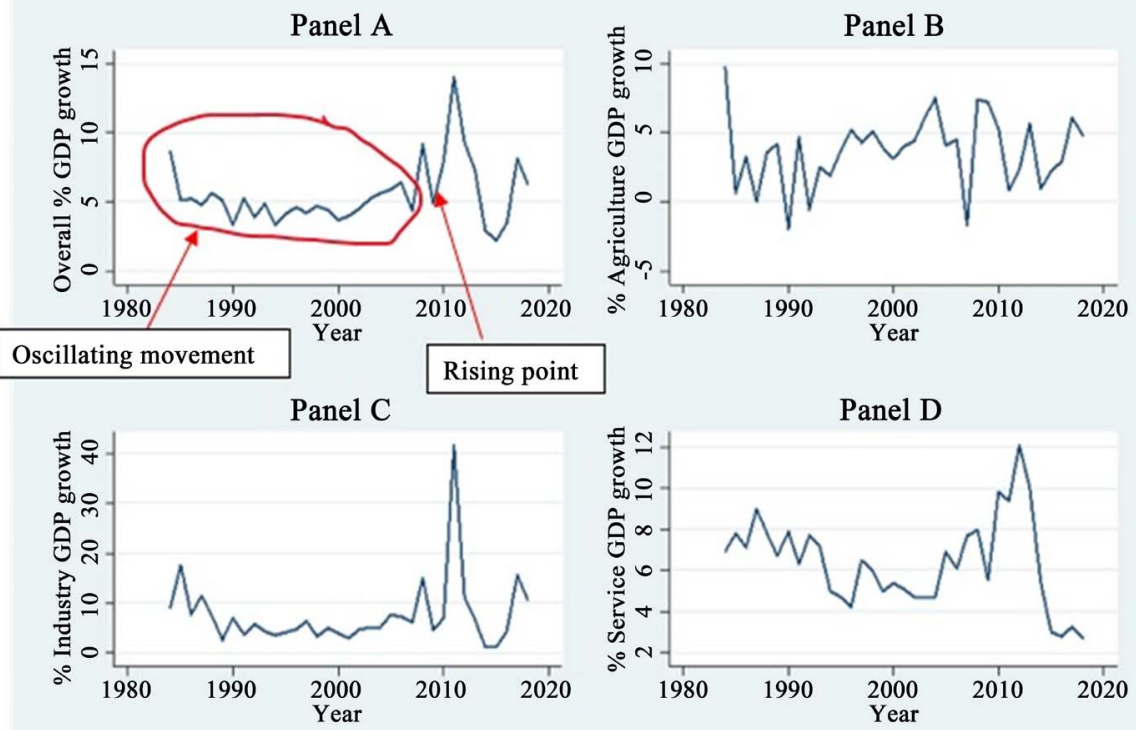

Figure 2. Percentage sectoral and overall GDP growth of Ghana (1984-2018). 
farmers who are mainly subsistence by nature. However, it was observed that the industrial sector (Panel C) witnessed a steady growth in terms of GDP over the years.

\subsection{Regression Analysis}

Before analyzing the relationship between overall GDP growth and the independent variables multiple tests were executed to ensure the suitability of the data for regression analysis.

\section{Test for Multicollinearity}

Following Ahsan, Abdullah, Fie, and Alam, (2009), Tolerance Level and Variance Inflation Factor (VIF) were examined to determine the presence of multicollinearity among the independent variables. In order to determine the existence of multicollinearity for a particular variable, tolerance level should be more than or equal to 0.01 and VIF values well below 10. As shown in Table 3, all the variables met the tolerance level and variance inflation factor. This suggests that there's no multicollinearity among the explanatory variables.

\section{Test of Linear Regression Assumptions}

A plot of the standardized residuals (Figure 3) shows a normally distributed residual error. Also, a normal probability plot (Figure 4) of standardized residuals with the observed cumulative probabilities of occurrence against expected

Table 3. Multicollinearity of diagnostics.

\begin{tabular}{ccc}
\hline Independent Variables & Tolerance & Variance Inflation Factor \\
\hline Agriculture & 0.8347 & 1.20 \\
Industrial & 0.8516 & 1.17 \\
Service & 0.9782 & 1.02 \\
\hline
\end{tabular}

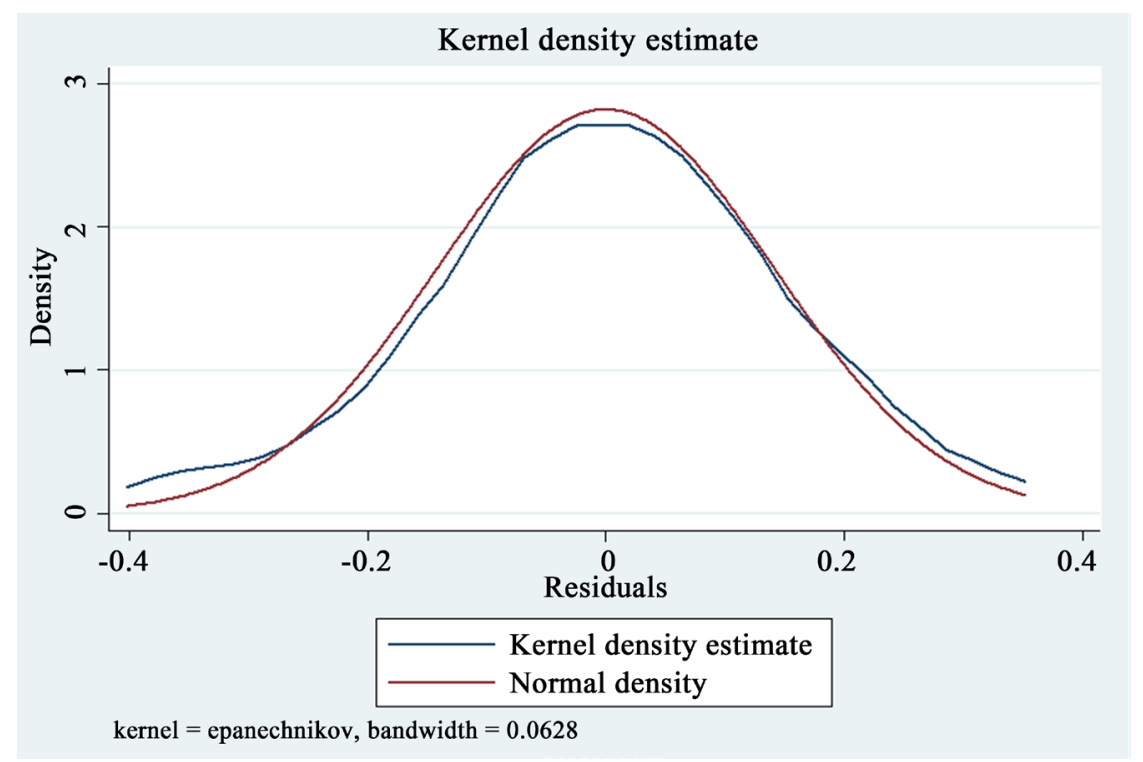

Figure 3. A plot of the standardized residual. 


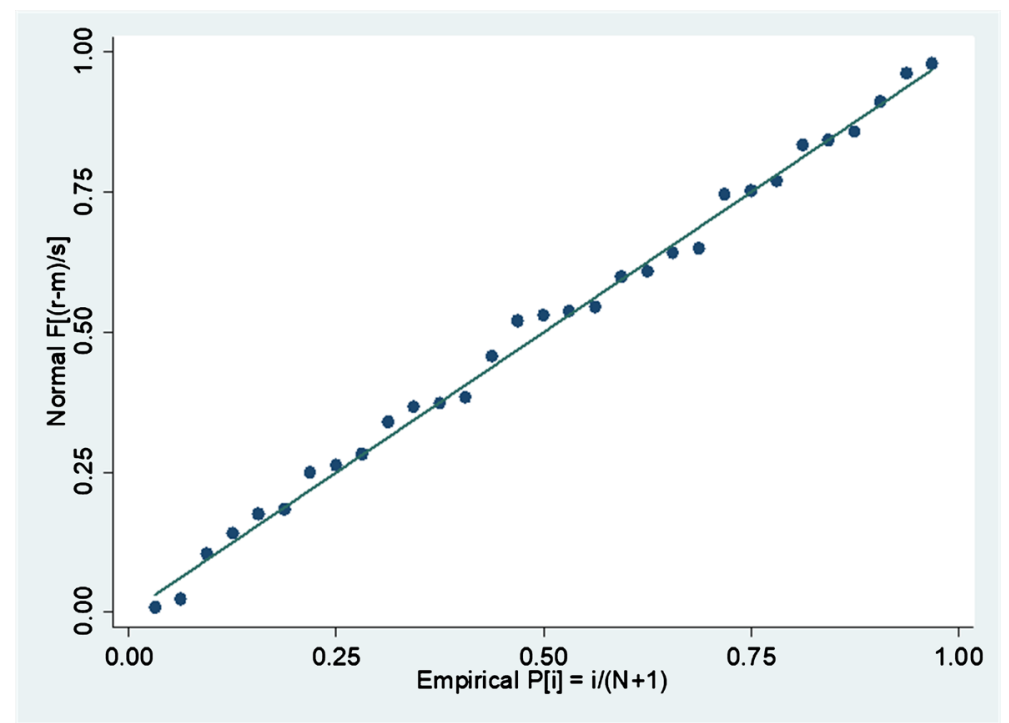

Figure 4. Normal P-P plot of standardized residual.

Table 4. Regression estimates of the relationship between overall GDP growth and sectoral growth.

\begin{tabular}{ccccc}
\hline Variable & Coefficient & SE & t-value & P-value \\
\hline Ln (Agriculture) & $0.1591^{\star *}$ & 0.0432 & 3.68 & 0.001 \\
Ln (Industry) & $0.3830^{* * *}$ & 0.0400 & 9.57 & 0.000 \\
Ln (Service) & $0.3287^{* * *}$ & 0.0811 & 4.05 & 0.000 \\
Constant & 0.2150 & 0.1533 & 1.40 & 0.172 \\
R-squared & 0.8617 & & & \\
No of Observations & 35 & & & \\
\hline
\end{tabular}

$* * *, * *$ and ${ }^{*}$ indicate statistical significance at $1 \%, 5 \%$ and $10 \%$ level.

normal probabilities show approximately linear plots, which conforms that the error terms are normally distributed.

\section{Regression Results}

To analyze the relationship between the various sectoral GDP growth and the overall GDP, the parameters of the estimates are presented in Table 4. The $\mathrm{R}$-squared explains the proportion of variation in the observed values of the response variable explained by the regression. It summarizes the proportion of variance in the dependent variable associated with the independent variables, with larger R-squared values indicating that more of the variation is explained by the model. A R-squared of 0.8617 was obtained suggesting that the degree of correlation between the dependent variable and the independent variable is $86.17 \%$.

The agricultural sector had a positive and significant effect on the overall GDP growth. This result is consistent with the findings of (Özel \& Okine, 2018) who had similar results in a study in Ghana. Besides, the industrial and service sector also contributed positively to the Overall GDP growth of the country. 


\section{Unit root test and order integration}

The unit root test for the variables employed in this study is presented in $\mathrm{Ta}$ ble 5 using the ADF and PP criteria. All the variables are not stationary at their level forms. I can reject the null hypothesis of ADF and PP and conclude that not all the variables are non-stationary.

To establish stationarity properties of the variables, I proceeded to differentiate the series. After first differencing all the variables except Service GDP become stationary, that is to say, and I can reject the null hypothesis of ADF and PP are different. Table 5 shows that all the series used in this study are all also not stationary after the first difference, and they are integrated of order I(1). Since some of the series are of order I(I), this necessitates us to carry out the Johansen cointegration test. This is done to investigate, if there is a possibility of long-run relationship among the series.

\subsection{Test for Co-Integration}

The order of integration, which enters the specified economic growth model, is already specified for each variable. All the variables are integrated of order one I (1). The next step is to estimate the long-run relationship between economic GDP growth and agricultural growth in Ghana using Johansson's maximum likelihood methods and the two steps Engel and Granger procedure. To proceed with the Johansen cointegration technique, the lag order and deterministic trend assumption for the VAR should be specified.

During the unit root test, the assumption of including constant but no trend was accepted.

Table 5. Unit Root for RealGDP, AgricGDP, IndusGDP and ServGDP.

\begin{tabular}{ccccccccc}
\hline Stationarity & lnRealGDP & lag & lnAgrGDP & lag & lnIndGDP & lag & lnSerGDP & lag \\
\hline Statistics (level) & & & & & & & & \\
$\tau_{T}$ (ADL) & $-3.841^{* *}$ & 0 & $-5.101^{* * *}$ & 0 & $-3.639^{* *}$ & 0 & -1.880 & 0 \\
$\tau$ (ADL) & $-3.700^{* *}$ & 0 & $-5.168^{* *}$ & 0 & $-3.717^{* *}$ & 0 & -1.590 & 0 \\
$\tau_{T}$ (PP) & $-3.825^{* *}$ & 0 & $-5.088^{* * *}$ & 0 & $-3.530^{* *}$ & 0 & -2.088 & 0 \\
$\tau$ (PP) & $-3.718^{* *}$ & 0 & $-5.159^{* *}$ & 0 & $-3.622^{* *}$ & 0 & -1.813 & 0 \\
Statistics (first difference) & & & & & & & \\
$\tau_{T}$ (ADL) & $-3.251^{*}$ & 1 & $-4.111^{* *}$ & 1 & $-3.786^{* *}$ & 1 & -1.845 & 1 \\
$\tau(\mathrm{ADL})$ & $-3.138^{* *}$ & 1 & $-3.780^{* *}$ & 1 & $-3.918^{* *}$ & 1 & -1.634 & 1 \\
$\tau_{T}$ (PP) & $-3.876^{* *}$ & 1 & $-5.088^{* *}$ & 1 & $-3.680^{* *}$ & 1 & -1.955 & 1 \\
$\tau(\mathrm{PP})$ & $-3.751^{* *}$ & 1 & $-5.155^{* *}$ & 1 & $-3.761^{* *}$ & 1 & -1.663 & 1 \\
\hline
\end{tabular}

lnRealGDP is the natural log of Real GDP of Ghana, lnAgrGDP is the natural log of agricultural GDP, lnIndGDP is the natural $\log$ of industry GDP, and $\operatorname{lnSerGDP}$ is the natural $\log$ of service GDP. $\tau_{T}$ represents a commonly used model with drift and trend; $\tau$ represents the rarely used model without drift and trend. ${ }^{* *}$, $*$, and ${ }^{*}$ indicate statistical significance at $1 \%, 5 \%$ and $10 \%$ level. 
Therefore, the deterministic trend assumption for the VAR excludes trends and includes constant. For the selection of the lag order, there are different types of lag selection criteria, which includes the sequentially modified likelihood ratio (LR), Akaike information criteria (AIC), Final prediction error (FPE), Schwarz information criterion (SC) and Hannan-Quinn information criterion (HQIC). However, it is not unusual that different criteria give a different number of maximum lag lengths. The problem is the choice of criteria to use. To overcome this problem, the model is run with different lag orders, chosen by different criteria and the LR test, and then implement the residual serial correlation and the residual normality test (Lütkepohl, 2005). An appropriate lag order needs to satisfy those tests. Therefore, in this study, the lag length selected by the Schwarz information criterion and Sequential Modified Likelihood Ratio approach fulfills these requirements, as well as prior knowledge of economic theory, are used. Table 6 shows the lag length chosen by different information criteria.

Table 7 presents the cointegration results for the series. From Table 7, we found one cointegrating vector for the model. We could reject the null hypothesis of no cointegrating vector. Thus, we accept the alternative hypothesis one cointegrating vector using Johansen trace statistic. This implies the non-existence of a long-run causality relationship between overall GDP growth, agricultural GDP, Service GDP, and industry GDP. Therefore, this does not qualify to run the restricted VECM.

Table 6. Results of the lag order selection criteria.

\begin{tabular}{ccccccccc}
\hline Lag & LL & LR & df & p & FPE & AIC & HQIC & SBIC \\
\hline 0 & -21.64 & & & & 0.00024 & 3.0168 & 3.0363 & 3.212 \\
1 & 11.13 & 65.55 & 16 & 0.00 & 0.00004 & 1.0431 & 1.1406 & 2.023 \\
2 & 35.15 & 48.04 & 16 & 0.00 & 0.00002 & 0.0998 & 0.2753 & 1.864 \\
3 & 85.90 & 101.49 & 16 & 0.00 & $1.5 \mathrm{e}-06^{*}$ & -3.9880 & -3.7347 & -1.439 \\
4 & 2105.5 & $4039.2^{*}$ & 16 & 0.00 & & $-239.706^{*}$ & $-239.375^{*}$ & $-236.373^{*}$ \\
\hline
\end{tabular}

*indicates the lag length selected by the criteria; LR: Sequential Modified likelihood; FPE: Final Prediction Error; AIC: Akaike Information Criterion; SBIC: Schwarz Bayesian Information Criterion; HQIC: Hannan-Quinn Information Criterion; ${ }^{* * *}{ }^{* *}$, and ${ }^{*}$ indicate statistical significance at $1 \%, 5 \%$ and $10 \%$ level.

Table 7. Johnsen multivariate cointegration results.

\begin{tabular}{cccc}
\hline Null hypothesis: $\mathrm{H}_{\mathbf{0}}$ & Eigenvalue & Trace statistic & 5\% Critical value \\
\hline $\mathrm{r}=0$ & & 81.5151 & 47.21 \\
$\mathrm{r} \leq 1$ & 0.7479 & 36.0379 & 29.68 \\
$\mathrm{r} \leq 2$ & 0.4585 & 15.7934 & 15.41 \\
$\mathrm{r} \leq 3$ & 0.2855 & 4.7018 & 3.76 \\
$\mathrm{r} \leq 4$ & 0.1328 & & \\
\hline
\end{tabular}

$* * *, *$, and ${ }^{*}$ indicate statistical significance at $1 \%, 5 \%$ and $10 \%$ level. 


\section{Conclusion and Recommendations}

\subsection{Conclusion}

It can be concluded that there's a positive relationship between agricultural GDP growth and overall GDP growth in Ghana. Again, the industrial and service sector contributes positively to the economic GDP growth of Ghana. The results of the unit-roots test indicated that all the variables are not stationary in first differences-I (1), therefore, I (1) series were adopted to test for cointegration and causality between overall economic GDP and agricultural GDP growth. The cointegration test results showed that there are no long-run relationships existing between the overall GDP and agricultural GDP growth and the other sectors.

\subsection{Recommendation}

The pressing policy recommendation that emerges from this study is that: the government should attempt to diversify and promote exports, especially agricultural exports, to fully exploit the benefits of the sector and promote economic growth. The government can do this by attracting new investment to the country through the provision of conducive and favorable environment for investors. Favorable environment can be in the form of good tax treatment to firms or the introduction of subsidies to firms in the form of cash incentive.

Again, the government should channel a lot of resources such as agricultural input interventions to boost smallholder production as they dominate the agricultural sector while at the same time encouraging them to be agribusiness minded.

The government of Ghana should improve resources and development investment in agricultural research and extension services to enhance the use of modern agricultural inputs. Finally, the government should exploit the other sectors to ensure the holistic contribution of the other sectors to the overall economic GDP growth of the country. The sectors that can be exploited can be either the service or industrial sector. These sectors dislodged the agricultural sector after 2018 and as such can be areas the government can exploit to help contribute to the overall economic GDP growth of the country.

\section{Acknowledgements}

Special thanks to Dr. Kwabena Nyarko Addai, Dr. Sunday Adiyoh Imanche, Dr. Israel Adikah for their immense contribution to this work.

\section{Conflicts of Interest}

The authors declare no conflicts of interest regarding the publication of this paper.

\section{References}

Ahsan, N., Abdullah, Z., Fie, D. Y. G., \& Alam, S. S. (2009). A Study of Job Stress on Job 
Satisfaction among University Staff in Malaysia: Empirical Study. European Journal of Social Sciences, 8 , 121-131.

Bonsu, D. (2014). Road Transport and Agriculture: A Comparative Study of the Implications of Road Access for Subsistence Agriculture in the Northern Ghana (p. 129).

Dickey, D. A., \& Fuller, W. A. (1981). Likelihood Ratio Statistics for Autoregressive Time Series with a Unit Root. Econometrica, 49, 1057-1072. https://doi.org/10.2307/1912517

Engle, R. F., \& Granger, C. W. J. (1987). Co-Integration and Error Correction: Representation, Estimation, and Testing. Econometrica, 55, 251-276. https://doi.org/10.2307/1913236

Enu, P. (2014). Analysis of the Agricultural Sector of Ghana and Its Economic Impact on Economic Growth. Academic Research International, 5, 267-277.

Granger, C. W. J. (1981). Some Properties of Time Series Data and Their Use in Econometric Model Specification. Journal of Econometrics, 16, 121-130. https://doi.org/10.1016/0304-4076(81)90079-8

Granger, C. W., \& Newbold, P. (1974). Spurious Regression in Econometrics. Journal of Econometrics, 2, 111-120. https://doi.org/10.1016/0304-4076(74)90034-7

Hayami, Y., \& Ruttan, V. W. (1971). Induced Innovation in Agricultural Development.

Johnston, B. F. (1970). Agriculture and Structural in Developing Transformation Countries: A Survey of Research. Journal of Economic Literature, 8, 369-404.

MoFA (2016). Agriculture in Ghana, Facts and Figures. Ministry of Food and Agriculture, Statistics, Research and Information Directorate (SRID), Statistics, Research and Information Directorate (SRID).

Nelson, C. R., \& Plosser, C. R. (1982). Trends and Random Walks in Macroeconmic Time Series: Some Evidence and Implications. Journal of Monetary Economics, 10, 139-162. https://doi.org/10.1016/0304-3932(82)90012-5

Oji-Okoro, I. (2011). Analysis of the Contribution of Agricultural Sector on the Nigerian Economic Development. World Review of Business Research, 1, 191-200.

Olajide, O. T., Akinlabi, B. H., \& Tijani, A. A. (2010). Agriculture Resource and Economic Growth in Nigeria. European Scientific Journal, 8, 103-115.

Özel, R., \& Okine, E. (2018). Gana Cumhuriyeti’nde Tarım ve Ekonomik Büyüme. Harran Tarım ve Gida Bilimleri Dergisi, 22, 363-375. https://doi.org/10.29050/harranziraat.421660

Peet, R. (1998). Modern Geographical Thought.

Perron, P. (1990). Testing for a Unit Root in a Time Series with a Changing Mean. Journal of Business and Economic Statistics, 8, 153-162. https://doi.org/10.1080/07350015.1990.10509786

Self, S., \& Grabowski, R. (2007). Economic Development and the Role of Agricultural Technology. Agricultural Economics, 36, 395-404. https://doi.org/10.1111/j.1574-0862.2007.00215.x

Sertoğlu, K., Ugural, S., \& Bekun, F. V. (2017). The Contribution of Agricultural Sector on Economic Growth of Nigeria. International Journal of Economics and Financial Issues, $7,547-552$.

Subramaniam, V. (2010). Agricultural Intersectoral Linkages and Their Contribution to Economic Development.

Tiffin, R., \& Irz, X. (2006). Is Agriculture the Engine of Growth? Agricultural Economics, 35, 79-89. https://doi.org/10.1111/j.1574-0862.2006.00141.x 
Timmer, C. P. (2005). Agriculture and Pro-Poor Growth: An Asian Perspective. https://doi.org/10.2139/ssrn.984256

Udemezue, J. C., \& Osegbue, E. G. (2018). Theories and Models of Agricultural Development Agricultural Development. Annals of Reviews and Research, 1, Article ID: 555574.

World Bank Sub-Sahara Africa Data \& Ghana Statistical Service (2020).

Zamora, M. D., \& Giddens, A. (1985). The Constitution of Society. Man, 20, 567-568. https://doi.org/10.2307/2802469 